\title{
Öğretmenlerin İş Yaşamı Kalitesi ile Örgütsel Değer Algıları Arasındaki İlişkinin İncelenmesi (Kayseri İli Örneği)*
}

\section{Venhar KAPLAN}

Gazi Üniversitesi Ĕ̆itim Fakültesi

ÖZ

Çalışmanın amacı, öğretmenlerin iş yaşamı kalitesi ile okulun örgütsel değer algıları arasındaki ilişkiyi saptamak ve bazı değişkenlere göre incelemektir. Araştırmanın desenleri korelasyon ve taramadır. Araştırma, Kayseri İli Kocasinan, Melikgazi ve Talas merkez ilçelerindeki ortaöğretim ve ilköğretim kurumlarındaki 568 öğretmenin katılımı ile gerçekleşmiştir. Öğretmenlerin iş yaşamı kalitesini belirlemek için "İş Yaşamı Kalitesi Ölçeği" ve okulun örgütsel değerlerini belirlemek için "Değerlere Göre Yönetim Ölçeği" kullanılmıştır. Verilerin analizinde, tanımlayıcı ve parametrik fark analizlerinden yararlanılmıştır. Elde edilen bulgular sonucunda, öğretmenler iş yaşamı kalite algılarına göre en fazla sosyal bütünleşme, güvenli ve sağlıklı çalışma koşulları; en az uygun ve adil karşılık, sosyal sorumluluk ve demokratik ortam boyutlarına sahiptir. Öğretmenler okulların örgütsel değeri olarak en fazla dürüstlük, insana saygı, adalet; en az dindarlık değerini benimsemişlerdir. İş yaşamı kalitesi ile okulun örgütsel değerleri arasında orta düzeyde pozitif yönde anlamlı bir ilişkinin olduğu bulunmuştur. Erkek öğretmenler kadın öğretmenlere göre demokratik ortam, güvenli ve sağlıklı çalışma koşulları ve uygun adil karşılık düzeyini daha yüksek; sınıf öğretmenleri branş öğretmenlerine göre iş gören kapasitesinin geliştirilmesi, güvenli ve sağlıklı çalışma koşulları, sosyal sorumluluk ve sosyal bütünleşmeyi daha yüksek bulmuştur. İlkokul öğretmenlerinin toplam yaşam alanı ve iş gören kapasitesinin geliştirilmesine yönelik algıları Anadolu lisesinde görev yapan öğretmenlere göre daha yüksek olduğu bulgusuna ulaşılmıştır.

Anahtar Kelimeler: İş yaşamı kalitesi, örgütsel değerler, öğretmen

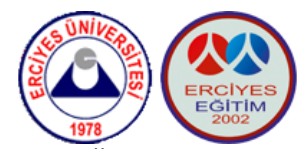

Erciyes Üniversitesi, Eğitim Fakültesi,

Kayseri/TÜRKIYYE

Erciyes Journal of

Education (EJE)

DOI: $10.32433 /$ eje. 820504

\section{SCREENED BY}

\section{iThenticate}

Tür: Araştırma

Makale Geçmişi

Gönderim : $\quad 03.11 .2020$

Kabul : $\quad 22.03 .2021$

Yayınlanma : 28.05.2021

\section{Önerilen Atıf}

Kaplan, V. (2021). Öğretmenlerin iş yaşamı kalitesi ile örgütsel değer algıları arasındaki ilişkinin incelenmesi. Erciyes Journal of Education, 5(1), 51-73. https://doi.org/10.32433/eje.820504

${ }^{*}$ Bu çalışma Tezli Yüksek Lisans Tezinin bir bölümünden alınarak uyarlanmıştır.

1. Dr., Eğitim Bilimleri, Eğitim Yönetimi, temeltasvenhar@gmail.com, https://orcid.org/0000-0002-1987-8951. 


\title{
Investigation of the Relationship between Teachers' Quality of Work Life and their Organizational Value Perceptions (the Case of the Kayseri Province)*
}

\author{
Venhar KAPLAN \\ Gazi University and Education Faculty
}

\begin{abstract}
The purpose of this study is to investigate the relationship between teachers' quality of work life and their organizational value perceptions and to analyze it in terms of some variables. The study uses the research designs of correlational research and survey. The study was conducted with the participation of 568 teachers in secondary and primary education institution in the central districts of Kocasinan, Melikgazi and Talas in Kayseri. In order to determine the quality of work life of teachers, "the Quality of Work Life Scale" was used, whereas "the Management by Values Scale" was used to determine their organizational value perceptions. Descriptive and parametric difference analyses were used in the analysis of the data. As a result of the study, according to the teachers' perceptions of their quality of work life, schools had the most social integration, safe and healthy working conditions, while they had the least appropriate and fair response, social responsibility and democratic environment dimensions. As organizational values, the teachers mostly considered integrity, respect for people and justice, and they adopted religious values the least. A moderate positive relationship was found between the participants' quality of work life and their organizational values. It was found that the male teachers had higher democratic environment, safe and healthy working conditions and appropriate and fair provision perception levels than the female teachers, and the form primary teachers were found to have higher perceptions on the development of the employee capacity, safe and healthy working conditions, social responsibility and social integration than the branch teachers. It was found that the perception of the primary school teachers towards the overall living space and development of the capacity of employees was higher than the teachers working at Anatolian high schools.
\end{abstract}

Keywords: Quality of work life, organizational values, teacher

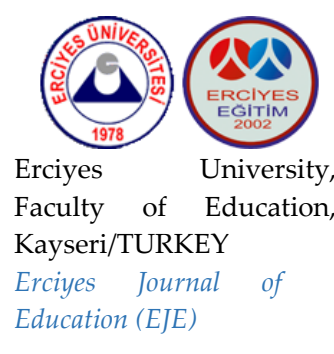

DOI: 10.32433/eje.820504

SCREENED BY

\section{iThenticate}

Type: Research

Article History

Received :03.11.2020

Accepted : 22.03.2021

Published : 28.05.2021

Suggested Citation

Kaplan, V. (2021). Investigation of the relationship between teachers' quality of work life and their organizational value perceptions (the Case of the Kayseri Province), Erciyes Journal of Education, 5(1), 51-73. https://doi.org/10.32433/eje.820504

"This study has been adapted from a part of the Master's Thesis.

1. PhD, Sciences of Education, Education Management, temeltasvenhar@gmail.com, https://orcid.org/0000-0002-19878951 


\section{EXTENDED ABSTRACT}

\section{Introduction}

In order to have a place in the society, the person has to undertake some duties and responsibilities. One of the most important of these responsibilities is their job. When slaves were performing jobs in the early days, there were significant changes in the components of business life as a result of innovation movements depending on social developments (Beach, 1980). One of the outputs obtained from these changes is the concept of quality of work life. "Quality of work life is the physical and psychological well-being of employees in the work environment in a manner that will lead to integration of the employee with the overall living space" (Bilgin, 1995, p.15). "Business life quality criteria include adequate and fair wages, safe and healthy working conditions, improving human capacities, opportunities for security, social integration at work, constitutionalism, work and overall living space and social appropriateness of work life" (Walton, 1975, p.91).

In the field of education that shapes the future of countries, the concept of quality of work life has been debated. It is considered important to improve teachers' quality of work life. In this context, to ensure the quality of teachers' work life, many programs need to be put in place to maintain the delicate balance between work and life. These programs are designed to improve the quality of work life, and by making them attractive, they will increase teachers' commitment to their organizations and result in success (Çokluk, 2003).

"Values are criteria that help characterize the work and actions of employees in daily life, serve to evaluate and judge. Determining values on both individual and organizational levels will facilitate understanding of organizational reality" (Hamm, 2006, p.3). The compatibility of organizational values and individual values will increase corporate success. "Additionally, it has been determined by various studies that this is also effective on the job satisfaction and motivation of employees" (Box et al., 1991, p.195; Hyde and Williamson, 2000, p.14; Kaya, 2008; O'Reilly et al., 1996, p.157; Rashid et al., 2003, p. 708). "At the school, which has the characteristics of an open and social system, the harmony of individual and organizational values is deemed necessary for the effectiveness of the school" (Feather and Rauter, 2004, p.81).

\section{Purpose}

The aim of this study is to investigate the relationship between teachers' quality of work life and their organizational values and to analyze it in terms of some variables. In this context, the data obtained from the participants were analyzed.

\section{Method}

The study was conducted with the correlational and survey design. The sample of the study consisted of 568 teachers working at primary and secondary schools in the central districts of the province of Kayseri in Turkey in the academic year of 2019-2020. The Quality of Work Life Scale was developed by Erdem (2008) and consists of seven dimensions. The Cronbach's Alpha reliability coefficient of the scale was calculated as .94 . As a result of KMO $(=.87)$ and Bartlett (= 
822.883, $\mathrm{p}=.000$ ) tests, the scale was found to be suitable for exploratory factor analysis. The factor load values of the seven dimensions ranged from .36 to .88 . The factors explained $77 \%$ of the total variance. The Management by Values Scale was developed by Yllmaz (2006). The Cronbach's Alpha coefficient of the scale was calculated as .96. As a result of KMO (=.88) and Bartlett $(=2456.142, \mathrm{p}=.000)$ tests, it was seen that the data were suitable for exploratory factor analysis. It was observed that the factor loads of the scale ranged from .34 to .87 . It was determined that $69 \%$ of the total variance was explained by these factors. Frequency, percentage distribution, arithmetic mean, standard deviation, t-test, one-way analysis of variance (ANOVA) and Tukey's HSD test were used in the analysis.

\section{Findings}

As a result of the study, the teachers exhibited the characteristic of social integration the most and the characteristic of appropriate and fair provision the least. As organizational values, they attached importance to the values of integrity, respect for people, justice, democracy and hard work. A moderately significant positive correlation was found between the teachers' perceptions of quality of work life and organizational values. Additionally, the dimensions of quality of work life, democratic environment, development of working capacity and appropriate and fair provision were significant predictors of the teachers' organizational value levels. The safe and healthy working conditions, democratic environment and appropriate and fair provision perceptions of the male teachers were more positive than those of the female teachers. The form primary teachers had higher perceptions of safe and healthy working conditions, development of working capacity, social responsibility and social integration in comparison to the branch teachers. The primary school teachers' the overall living space and working capacity of employees were more positive than the teachers working at Anatolian high schools. Additionally, the primary school teachers' social responsibility, social integration, democratic environment, appropriate and fair provision perception levels were determined to be higher than those of the vocational high school teachers.

\section{Discussion E Conclusion}

In the study, it was determined that the teachers showed social integration on the highest levels and the appropriate and fair provision characteristic on the lowest levels. In parallel with this result, Taşdan and Erdem (2010) found that teachers had the highest social integration and democratic environment characteristics in their study, while they determined that the participants took part in the appropriate and fair provision dimensions the least. Similar findings were determined by Baleghizadeh and Gordani (2012), Demir (2016), Demir (2019), Hart (1994), Kösterelioğlu (2011), Yalçın (2014). This result may have been due to the teachers' dissatisfaction with their salary, retirement conditions, health and personal rights. The organizational values in which the teachers participated the most were honesty, respect for people and justice. This finding was in line with the results of the studies by McDonald and Gandz (1992), Özmete and Gönen (1997), Sağnak (2005), Taşdan (2006), Taşdan (2010), Taşdan and Erdem (2010) and Yılmaz (2006) In the study, a moderately significant positive relationship was determined between the teachers' perceptions of quality of work life and organizational values. This finding was similar to the results reported by Özmete and Gönen (1997) and Taşdan and Erdem (2010). The teachers' democratic environment, development of capacity to work and appropriate and fair provision dimensions were positive predictors of their organizational values. The male teachers had more positive perceptions of democratic environment, appropriate and fair provision and safe and 
healthy working conditions than the female teachers. The results reported by Erdem (2008), Karakaya and Çoruk (2017), Toygar et al. (2018) and Y1lmaz (2014) supported these findings. The form primary teachers' perceptions of safe and healthy working conditions, development of capacity to work social responsibility and social integration were higher than those of the branch teachers. Divins et al. (1991) reported results that were in parallel with this study. Unlike the results of this study, in the studies conducted by Çelik and Tabancalı (2012) and Yılmaz (2014), no significant difference was found between teachers' branch variable and their perceptions of quality of work life. The primary school teachers' level of development of capacity to work and the overall living space and working capacity was higher than the teachers working at Anatolian high schools. Additionally, the primary school teachers' perceptions of social responsibility, social integration, democratic environment and appropriate and fair provision were higher than those of the vocational high school teachers. According to Yllmaz (2019), primary school teachers' perceptions of social integration, social responsibility and improving their capacity to work are on a higher level than those of high school teachers.

\section{Gíriş}

Günümüz toplumlarında yer edinebilmek için kişiler birtakım görev ve sorumlulukları üstlenmek zorundadır. Bu sorumlulukların önemlilerinden biri olan unsur da işidir. "Illk dönemlerde işleri köleler yaparken, toplumsal gelişmelere bağlı olarak yenileşme hareketleri sonucunda iş hayatının bileşenlerinde önemli değişiklikler yaşanmıştır" (Beach, 1980, s.64). Bu değişimlerden elde edilen çıktılardan biri de iş yaşamı kalitesi kavramıdır. İş yaşamı kalitesi kavramı, çalışanların bütün şekilde yaşama alanlarıyla bütünleşebilmesine sebep olacak yönde, çalışanların çalışma ortamındaki psikolojik ve fiziksel olan iyi oluş durumlarıdır (Bilgin, 1995). Başka bir tanımda ise iş yaşam kalitesi, çalışanların iş ortamlarının değerlendirilmesi, işgörenlerin memnuniyet ve memnuniyetsizlik halleri, verimli olma durumları, sosyal ortam, yönetim şekli, iş dışındaki yaşamın ve iş hayatının birbiri arasındaki ilişki durumu; kısacası çalışma ortamının bütünündeki zayıf ve güçlü tarafları içerisine alan kavram olarak bilinmektedir (Martel ve Dupuis, 2006). İş yaşamı kalitesi kavramı ilk olarak alan yazına 1973'te yayınlanan bir makale ile açıklık getirilmiştir. Buna göre "iş yaşamı kalitesi kriterleri; adil ve yeterli bir ücret, sağlıklı ve güvenli çalışma koşulları, kişisel kapasitelerini kullanabilmek ve geliştirmek adına hazır olan fırsatlar, güvenlik ve devamlı büyüme için fırsatlar, çalışma ortamındaki sosyal bütünleşme, iş, toplam yaşam alanı, meşrutiyet, iş yaşamının sosyallik yönünden uygunluğu" olarak sıralanmıştır (Walton, 1975, s.91).

Ülkelerin geleceğine şekil veren eğitim alanında da iş yaşamı kalitesi kavramı tartışılır olmuştur. Öğretmenlerin iş yaşamı kalitelerinin iyileştirilmesi önemli görülmektedir. “Bu iyileştirme sadece öğretmeni değil eğitimin diğer paydaşları olan öğrenci, veli, toplumu da ilgilendirmektedir. Günümüz eğitim alanında öğretmenlerin iş alanları çok boyutlu olup sadece öğretim faaliyetleri ile sınırlandırılmamıştır. Öğretmenler aynı zamanda öğrenciler, veliler, ders programları, okul toplulukları ve alanları ile ilgili pek çok görevde yer almaktadırlar (Pillay vd., 2005). Bu kapsamda öğretmenlerin çalışma ve yaşam arasındaki hassas dengeyi sağlamak, iş yaşam kalitesini sağlamak adına birçok programın devreye konulması gereklidir. Bu programlar çalışma hayatındaki kaliteyi iyileştirerek çekici duruma getirecek bu sayede öğretmenlerin örgütlerine olan bağlılık düzeylerini artıracak ve başarıyı doğuracaktır (Çokluk, 2003). Öğretmenin okuluna ve işlerine bağlllık hissetmesi, işlerinden doyum elde edebilmesi, 
tükenmişlik ve stresle başa çıabilmesi, veli, öğrenci ve iş arkadaşlarıyla güçlü ve etkin ilişkiler kurmasına, kısaca iş yaşamı kalite algısının güçlü olabilmesi başarılı olabilmesinde ana unsur olarak değerlendirilmektedir (Taşdan ve Erdem, 2010). Öğretmenlerin çaba ve emeklerinin yeterli olarak takdir görmemesi, kaynak yetersizlikleri ve eğitim imkanlarının kısıtlılığı, ödüllendirme sisteminde adil olunmaması, kendilerini direk olarak etkileyebilecek kararlarda söz haklarının kısıtlı olması, bürokratik engeller iş yaşamı kalitesini olumsuz etkilemektedir. Ayrıca öğretmenlerin toplum içindeki statüsünün zamanla azalması, öğretmen ilişkileri ile okul yönetiminin iyi olmaması, eğitim sisteminde sık sık değişiklik yapılması, kendini geliştirebilme ve terfi imkanlarının az olması gibi faktörlerin işi yaşamındaki kaliteyi negatif yönde etkilemektedir (Çokluk, 2003; Elma, 2003). Yaşanan olumsuzluklar ise eğitim-öğretim sisteminin kalitesini düşürmektedir. İş yaşamı kalitesinin düşük düzeyde olduğu okullar, öğretmenin işini olumsuz olarak etkileyerek motivasyon, ilişki, iş doyumu, örgütsel bağlılıkları ve iş yaşamı dengelerini de etkileyecektir (Barker, 1986; Bolduc, 2002).

Değerler, çalışanların günlük hayattaki iş ve faaliyetlerini nitelendirmek, değerlendirmek ve yargılamak için kullanılan ölçütlerdir. Tarihsel dönemlerden itibaren değer kavramı üstünde en çok konuşulan konulardan biri olmuş ve değerin toplum ve birey üzerinde önemli etkisinin olması hali tartışılmıştır. Değer, kişilerin içerisinde bulunduğu örgüt içi olay, olgu ve diğer bireyleri değerlendirebilmelerinde yardımcı olmaktadır. Bu sebeple bir örgütün sahip olduğu değerler ve uygulamalar, örgüt içindeki kişilerin davranışlarının yanında, örgüt ile ilişki duurmu olan diğer örgütler ve kişilerin de uygulama ve davranışlarını da etkilemektedir (Lewis vd., 1998). “Örgütsel değer, sosyalleşme ve seçme süreciyle beraber örgüt-birey uyumunda da yardımcı olabilmektedir" (O'Reilly ve Chatman, 1996, s.487). Değerin hem örgütsel hem de bireysel durumda belirlenebilmesi örgütsel gerçeklik halinin anlaşılmasını kolaylaştıracaktır" (Hamm, 2006, s.3). "Örgütsel ve bireysel değerlerin uyumluluğunun sağlanabilmesi sonucunda, çalışanların daha verimli ve etkili olabilmelerini sağlamaktadır" (Mc Donald ve Gandz, 1991, s.217). Örgütün sahip olduğu değerler ile çalışan bireylerin sahip olduğu değerlerin uyum içinde olabilmesi örgütsel başarı halini yükselteceği gibi çalışanların güdülenmesi ve iş doyumunun sağlanması için etkin olduğu farklı çalışmalarla belirlenmiştir (Box vd., 1991; Hyde ve Williamson, 2000; Kaya, 2008; O'Reilly ve Chatman, 1996; Rashid vd., 2003). Sosyal ve açık bir sistem olan okullarda, örgütsel ve kişisel değerlerin uyum içinde olabilmesi okulların etkin olabilmesi adına zorunlu kılınmaktadır (Feather ve Rauter, 2004). Örgüt-birey uyumu ile meydana gelen işi dair doyum, örgütsel vatandaşlık, örgütsel bağlllık ve performans düzeyleri aralarında doğru yönlü ilişkilerin olabilmesi, okullarda öğretmenin kişisel değerleriyle okulun kültür anlayışını yansıtan örgütsel değerin uyum halinin önem düzeyini yükseltmektedir (Chatman, 1989; O’Reilly vd., 1991). Okulun örgütsel değerleri, okul yönetimi ve öğretmenlerin benimsediği genel inançlarla beslenmektedir. Okulun kültürü içine daha sonra gelen öğretmen ya değerleri direk kabul eder, ya da kabul eder gibi görünerek reddedebilir. Bu bağlamda sosyallik durumunda olan okulların türü ve yapısına göre öğretmenlerde de belirli ortak değerler sistemi meydana gelir (Pang, 1996). Öğretmenlerin değerleriyle okulun değerlerinin uyumlu olması işin insancıllaştırılması ile ilgilidir. İşin insancıllaştırılması için ilk adım öğretmenin sosyal, psikolojik ve akademik ihtiyaçlarının karşılanabilmesi ve iş ortamının iyileştirilebilmesi kısaca iş yaşamı kalite algılarının yükseltilmesine bağlıdır (Taşdan ve Erdem, 2010)

İlgili alan yazın incelendiğinde, iş yaşam kalitesi ve örgütsel değerlere göre çeşitli örneklem durumları ile yapılmış birden çok çalışmaya rastlanmıştır (Akman ve Akman, 2017; Barker, 1986; Beechem, 1985; Demir, 2016; Demir, 2019; Erdem, 2008; Erdem, 2010; Gizzi, 1988; Posner vd., 1985; Safrit vd., 1994; Shobe, 1983; Taşdan ve Erdem, 2010; Uyan, 2002; Yalçın vd., 2016; Yılmaz, 2007). 
Öğretmenlerin iş yaşamı kalitesi ile örgütsel değerleri arasındaki ilişkiyi belirleyen yeterli çalışma bulunmamaktadır. Bu kapsamda öğretmenlerin iş yaşamı kalitesini etkilediği varsayılan, okula ait örgütsel değer algıları ele alınmış, iş yaşamı kalitesi ile okulun örgütsel değerleri arasındaki ilişki araştırılmış ve demografik değişkenlere göre araştırılmıştır.

Bu hedefe ulaşabilmek adına aşağıda yer alan sorulara cevap aranmıştır:

1. Öğretmenlerin iş yaşamı kalitesine ilişkin görüşleri ne düzeydedir?

2. Öğretmenlerin örgütsel değerlere okullarda ne düzeyde önemsendiğine ilişkin görüşleri nedir?

3. Öğretmenlerin iş yaşamı kalite algıları ile okulların önemsediği örgütsel değerler arasında anlamlı bir ilişki var mıdır?

4. Öğretmenlerin iş yaşamı kaliteleri, okulların önemsediği örgütsel değer algılarını anlamlı şekilde yordamakta mıdır?

5. Cinsiyet, branş ve okul türü değişkenleri ile öğretmenlerin iş yaşamı kalite algıları arasında anlamlı farklılık bulunmakta mıdır?

Araştırma öğretmenlerin iş yaşam kalitelerinin ve örgütsel değer algılarının belirlenmesi ile Millî Eğitim Bakanlığının öğretmen değerlendirme alanlarına da yardımcı olabilmesi, bu alan için araştırma yapmak isteyen akademisyen kişilere öncülük edebilmesi açısından iş yaşam kalite anlayışını azaltan etmenlerin belirlenerek ortadan kaldırılması bakımından önemlidir. İş yaşamı kalitesi ve örgütsel değerlerin saptanması, okuldaki diğer çalışanlara sağlanacak okul iklimi ve iş yaşamı kalite unsurlarının meydana gelmesi ve güçlendirilebilmesi yönünden de önemli bir çalışmadır. Ayrıca Kayseri ilindeki öğretmenlerin iş yaşamı kalite algıları ile okulun örgütsel değer algıları arasındaki ilişki üzerinde duran ilk çalışma olması açısından ilgili alan yazındaki boşluğu doldurabilmesi beklenmektedir.

\section{YÖNTEM}

\section{Araştırmanın Modeli}

Öğretmenlerin iş yaşamı kalite algıları ile okulların örgütsel değerleri arasındaki ilişkinin değerlendirildiği nicel alandaki bir araştırma olan çalışmada kolerasyonel araştırma analiz tekniği kullanılmıştır. İlişkisel araştırma olarak da bilinen kolerasyonel araştırmada, değişkenlere müdahale yapılmadan ikili veya daha çok sayıdaki değişkenler arasındaki ilişki durumunun tespit edildiği çalışmalardır (Fraenkel ve Wallen, 2009). Bu noktadan yola çıkarak iş yaşamı kalitesi ile örgütsel değerler arasındaki ilişkiyi belirlemek ve yordamak için kolerasyon ve tarama deseni kullanılmıştır.

\section{Çalışmanın Evren ve Örneklemi}

Araştırmanın evreni 2018-2019 eğitim öğretim yılının ikinci dönemi Kayseri ili merkez ilçelerinde görev yapmakta olan 8964 öğretmenden oluşmaktadır. Araştırmanın çalışma grubunu ise 8964 öğretmenden, olasılık temelli olmayan örnekleme yöntemlerinden gelişigüzel örnekleme yöntemi ile belirlenen 568 öğretmen oluşturmaktadır. Gelişigüzel örneklemede, çalışan kişinin belirlemiş olduğu örneklem sayısı büyüklüğüne göre evren içinden kendi görüşleri açısından bir bölümün seçilmesini sağlayan örnekleme yöntemidir (Tanrı̈ğen, 2009). “Evren içerisinden örnekleme alınması gereken öğretmenlerin sayı olarak saptanması için şu formül tercih edilmiştir" (Tanriöğen, 2009, s.126): 


$$
n=\left(t^{2} x p x q / d^{2}\right) /\left(1+1 x t^{2} x p x q / N d^{2}\right)
$$

Formüldeki simgeler ise;

$\mathrm{N}$ : Evren büyüklüğü

n: Örneklem büyüklüğü

t: Güven düzeyi $(\alpha=0,05$ için 1,$96 ; \alpha=0,01$ için 2,58)

p: Olayın görülme sıklığ $(q=1-p)$

q: Olayın gerçekleşmeme sıklığı

$\mathrm{d}$ : Tolerans düzeyi $(\mathrm{d}=0.05)$

Araştırmadaki örneklemin sayısını tespit etmek için belirlenmiş değerler, yazıldığında:

$$
n=\frac{(1,96)^{2} x \frac{0,5 \times 0,5}{(0,05)^{2}}}{1+\frac{1}{8964} x(1,96)^{2} x \frac{0,5 \times 0,5}{(0,05)^{2}}}=368,39
$$

Örneklem büyüklüğü, verilen formülde gerekli işlemlerin yapılması sonucunda minimum 368 kişi olarak belirlenmiştir. Ancak, verilerin toplanması aşamasında uygulamada karşılaşılabilecek olası güçlüklerden en az şekilde etkilenmek, hesaplanan örneklem büyüklüğünün altına düşmemek ve örneklem sayısının geçerlilik düzeyini artırabilmek adına 368'den daha fazla öğretmene ulaşabilmek amaçlanmıştır. Bu kapsamda 568 öğretmen örnekleme dâhil edilmiştir. Çalışma grubunun kişisel özellikleri Tablo 1'de verilmiştir:

Tablo 1. Katılımcıların kişisel özellikleri

\begin{tabular}{lccc}
\hline Değişken & Düzey & $\mathbf{f}$ & $\mathbf{\%}$ \\
\hline \multirow{2}{*}{ Cinsiyet } & Kadın & 257 & 45.2 \\
& Erkek & 311 & 54.8 \\
\hline \multirow{2}{*}{ Branş } & Sinıf Öğretmeni & 171 & 30.0 \\
& Branş Öğretmeni & 397 & 70.0 \\
\hline \multirow{2}{*}{ Okul Türü } & İlkokul & 133 & 23.4 \\
& Ortaokul & 138 & 24.3 \\
& Anadolu Lisesi & 131 & 23.1 \\
& İmam Hatip Lisesi & 80 & 14.1 \\
& Meslek Lisesi & 86 & 15.1 \\
\hline \multirow{2}{*}{ Mesleki Kıdem } & $1-4$ yıl & 39 & 6.9 \\
& $5-8$ yıl & 74 & 13.0 \\
TOPLAM & $9-13$ yll & 128 & 22.5 \\
\hline
\end{tabular}

Tablo 1 incelendiğinde, öğretmenlerin 257'sinin (\% 45.2) kadın, 311'nin (\% 54.8) erkek, 397'sinin (\% 70) branş öğretmeni, 171'nin (\% 30) sinıf öğretmeni, 133'nün (\% 23.4) ilkokul, 138'nin (\% 24.3) ortaokul, 131'nin (\% 23.1) Anadolu lisesi, 80'nin (\% 14.1) imam hatip lisesi, 86'sinin (\% 15.1) meslek lisesinde görev yaptıkları, 39'nun (\% 6.9) 1-4 yıl, 74'nün (\% 13) 5-2 yıl, 128' nin (\% 22.5) 913 yıl, 327'sinin (\% 57.6) 14 yıl ve üzerinde mesleki kıdem süresinde oldukları belirlenmiştir. 


\section{Veri toplama araçları}

Bu çalışmada veri toplama aracı olarak Kişisel Bilgi Formu, Kişisel Bilgi Formu, İş Yaşamı Kalite Ölçeği (Erdem, 2008) ve son olarak Değerlere Göre Yönetim Ölçeği (Yılmaz, 2006) tercih edilmiştir.

\section{Kişisel Bilgi Formu}

Araştırmacı tarafından hazırlanmış olan kişisel bilgi formu; katılımcıların cinsiyet, branş, okul türü ve mesleki kıdem değişkenlerinden oluşmaktadır.

\section{İş Yaşamı Kalitesi Ölçeği}

Araştırmada ilk veri toplama aracı olarak "İş Yaşamı Kalitesi Ölçeği" (Erdem, 2008) tercih edilmiştir. Erdem (2008) yılında geliştirilen bu ölçek, güvenli ve sağlıklı çalışma koşulları, toplam yaşam alanı, sosyal sorumluluk, iş gören kapasitesinin geliştirilmesi, sosyal bütünleşme, uygun ve adil karşlık ve demokratik ortam olmak üzere yedi alt boyuttan ve 58 alt maddeden oluşmaktadır. Ölçek 5'li likert tipinde hazırlanmış puanlandırmada, tamamen katılıyorum (4.205.00), çok katılıyorum (3.40-4.19), katılıyorum (2.60-3.39), az katılıyorum (1.80-2.59), katılmıyorum (1-1.79) şeklindedir. İş yaşamı ölçeğinin güvenirlik katsayısını (Cronbach Alpha) alt boyutlara gösteren tablo Tablo 2'de verilmiştir:

Tablo 2. İs yaşamı kalitesi ölçeğinin standart sapma, ortalama ve güvenirlik değerleri

\begin{tabular}{lccc}
\hline Alt Boyutlar & $\boldsymbol{x}$ & ss & $\boldsymbol{\alpha}$ \\
\hline 1. Toplam Yaşam Alanı & 3,35 & 1,04 &, 78 \\
\hline 2. Güvenli ve Sağliklı Yaşam Koşulları & 3,44 & 1,04 &, 82 \\
\hline 3. İş Gören Kapasitesinin Geliştirilmesi & 3,29 & 1,03 &, 80 \\
\hline 4. Sosyal Sorumluluk & 3,19 & 1,00 &, 85 \\
\hline 5. Sosyal Bütünleşme & 3,55 & 0,85 &, 88 \\
\hline 6. Demokratik Ortam & 2,76 & 1,22 &, 86 \\
\hline 7. Uygun ve Adil Karşılık & 2,67 & 1,05 &, 84 \\
\hline Toplam & 3,18 & 1,03 &, 94 \\
\hline
\end{tabular}

Tablo 2 incelendiğinde, iş yaşamı kalitesine ait alt boyutlarının standart sapma ve güvenirlik değeri olarak en homojen olan değer sosyal bütünleşme, en az homojen değer ise demokratik ortam alt boyutlarında olmuştur. Güvenirlik hali incelendiğinde ise güvenirliği en yüksek düzeyde olan alt boyut sosyal bütünleşme, güvenirlik açısından en düşük düzeyde olan alt boyut toplam yaşam alanıdır. Kaiser-Meyer-Olkin (KMO) ve Bartlett (Bartlett's Test of Sphericity) analizleri yapılmıştır. KMO (=.87) ve Bartlett $(=822.883, p=.000)$ analizleri sonucunda verilerin açımlayıcı faktör analizi (Afa) uygun olduğu belirlenmiştir. İ̧̧ yaşamı kalitesi ölçeğinde geçerlilik analizindeki doğrulayıcı faktör analizine ait değerlere göre: $\frac{x 2}{d f}=2,17 \quad\left(x^{2}=398,8, d f=183,7\right)$; $\mathrm{GFI}=0,745$, AGFI=0,85, NNFI=0,74, karşılaştırmalı uyum indeksi ise $\mathrm{CFI}=0,90$, kök ortalama kare yaklaşım hatası ise RMSEA=0,058, Tucker-Lewis indeksi (TLI) değeri ise 0,91dir. Karşılaştırmalı uyum indeksi (CFI) ve Tucker-Lewis indeksi (TLI) değerinin 0,90 ve üzerinde olması açısından iyi derecede uyum sağlamış olduğu anlamına gelmektedir (Şimşek, 2007). Yedi alt boyutun ise faktör yükleri .36-.88 arasında değişmektedir. İş yaşamı kalitesi ölçeğinin toplam varyansının 
\%77'sini açıklamaktadır. "İş Yaşamı Kalitesi Ölçeği" nin güvenilir ve geçerli bir ölçme aracı olması açısından güçlü kanıtlar bulunmuştur.

\section{Değerlere Göre Yönetim Ölçeği}

Araştırmada kullanılan diğer ölçme aracı "Değerlere Göre Yönetim Ölçeği” dir. Yılmaz 2006 yılında geliştirilmiş olan ölçek 29 alt maddeden oluşmuştur. Ölçek 5'li likert tipindedir. Puanlamada ise (4.20-5.00) tamamen katıllyorum, çok katılıyorum (4.19-3.40), katıllyorum (3.392.60), (2.59-1.80) az katılıyorum ve (1.79-1.00) katılmıyorum şeklindedir. Ölçeğin iç tutarlılık katsayılarını (Cronbach Alpha) 96 olarak hesaplanmıştır. (KMO) Kaiser-Meyer-Olkin ve Barlett (Barlett's Test of Sphericity) analizleri yapılmıştır. KMO (=.88) ve Barlett (=2456.142, $p=.000)$ analizleri sonunda değerlerin açımlayıcı faktör analizine uygun olduğu belirlenmiştir. Değerlere göre yönetim ölçeğinin doğrulayıcı faktör analizine ilişkin değerleri: $\frac{x 2}{d f}=2,842\left(x^{2}=704,882\right.$, $d f=248), \mathrm{SRMR}=0,065$, AGFI=0,81, GFI=0,840, CFI= 0,951, NFI=0,930, NNFI=0,950, RMSEA=0,0680. Ölçeğin faktör yüklerinin .41-.78 arasında değiştiği görülmüştür. Değerlere göre yönetim ölçeği toplam varyansın \%69'nu açıladığı belirlenmiştir.

\section{Verilerin Analizi}

Çalışmada verilerin analizinde, kişisel bilgi formu, iş yaşamı kalitesi ölçeği ve değerlere göre yönetim ölçeklerinden elde edilecek olan verilerin aracıllğı ile "SPSS 22.0" paket programı kullanılarak gerçekleştirilmiştir. İş yaşamı kalitesi ve değerlere göre yönetim ölçeğinin normal dağılım gösterip göstermediği belirlenmiş, bu bağlamda çarpıklık ve basıklık kritik değeri olarak bunun için de basıklık çarpıklık kritik değeri \pm 1.96 aralığında olması göz önüne alınmışır (Tabachnick ve Fidell, 2007). Örneklem grubunun 50'den fazla sayıda olması nedeniyle, Kolmogorov-Smirnov normallik analizi yapılmıştır. İş yaşamı kalitesi ölçeği için basıklık değeri $(=-0,390)$ ve çarpıklık değeri $(-1,063), p<.05$; Değerlere göre yönetim ölçeği için basıklık değeri $(=-$ $0.018)$ ve çarpıklık değeri $(-0,990) p<.05$. İstatistiksel işlemler için anlamlılık düzeyi .05 olarak alınmıştır. Bu değerlerden hareketle dağılımın normale yakın değere olduğu söylenebilir. Bu sebeple çalışmada elde edilen verilerin analizinde parametrik testler kullanılmıştır. Çalışmada tanımlayıcı (standart sapma, aritmetik ortalama) ve parametrik (ilişkisiz t-Testi ve ANOVA Varyans analizi) fark analizleri ile yapılmıştır.

\section{BULGULAR}

Araştırmanın birinci alt amac1; öğretmenlerin iş yaşamı kalitesine ait görüşleri ne düzeydedir, olarak düzenlenmiştir. Tablo3' de öğretmenlerin iş yaşamı kalitesine ait görüşleri verilmiştir:

Tablo 3. Öğretmenlerin iş yaşamı kalitesine ait görüşleri

\begin{tabular}{lccc}
\hline Boyutlar & $\boldsymbol{N}$ & $\boldsymbol{x}$ & $\boldsymbol{s}$ \\
\hline Toplam Yaşam Alanı & 568 & 3,35 & 1,04 \\
\hline Güvenli ve Sağlıklı Yaşam Koşulları & 568 & 3,44 & 1,04 \\
\hline İş Gören Kapasitesinin Geliştirilmesi & 568 & 3,29 & 1,03 \\
\hline Sosyal Sorumluluk & 568 & 3,19 & 1,00 \\
\hline Sosyal Bütünleşme & 568 & 3,55 & 0,85 \\
\hline
\end{tabular}




\begin{tabular}{llll}
\hline Demokratik Ortam & 568 & 2,76 & 1,22 \\
\hline Uygun ve Adil Karş1lık & 568 & 2,67 & 1,05 \\
\hline Toplam & $\mathbf{5 6 8}$ & 3,18 & 1,03 \\
\hline
\end{tabular}

Tablo 3 incelendiğinde, öğretmenler en fazla sosyal bütünleşme $(x=3,55, \mathrm{ss}=0,85)$ en az ise uygun ve adil karşılık ( $x=2,67$, ss=1,05) alt boyutlarına katılım göstermektedir. Başka bir deyişle, öğretmenlerin görüşleri en çok sosyal bütünleşme en az ise uygun ve adil karşılık boyutundadır.

Araştırmanın ikinci alt amacl; öğretmenlerin örgütsel değerlere okullarda ne düzeyde önemsendiğine ilişkin görüşleri nedir, şeklindedir. Tablo 4'de öğretmenlere göre örgütsel değerlerin okullarda ne düzeyde önemsendiğine yönelik görüşleri verilmiştir:

Tablo 4. Öğretmenlere göre okullarda önemsenen örgütsel değerlerin düzeyi

\begin{tabular}{lcc}
\hline Örgütsel Değerler & $x$ & $s s$ \\
\hline 1.Açılık & 4,09 & 1,27 \\
\hline 2.Adalet & 4,19 & 0,99 \\
\hline 3.Bă̆ımsızlık & 4,11 & 0,97 \\
\hline 4.Bağllık & 3,85 & 0,98 \\
\hline 5.Başarılı olmak & 4,17 & 0,95 \\
\hline 6.Bilimsellik & 4,06 & 1,00 \\
\hline 7. Çalışkanlık & 4,17 & 0,97 \\
\hline 8. Demokrasi & 4,18 & 0,96 \\
\hline 9. Dindarlık & 3,70 & 0,99 \\
\hline 10.Dürüstlük & 4,23 & 1,00 \\
\hline 11.Eşitlik & 4,13 & 0,99 \\
\hline 12.Fedakârlık & 4,14 & 1,02 \\
\hline 13.İnsana Sayg1 & 4,20 & 0,99 \\
\hline 14.İ̀s birliği & 4,15 & 1,01 \\
\hline 15.İyilikseverlik & 4,05 & 1,02 \\
\hline 16.Laiklik & 4,06 & 0,99 \\
\hline 17.Otoriteye sahip olmak & 3,84 & 1,01 \\
\hline 18.Özdenetim & 3,73 & 0,98 \\
\hline 19.Özsaygı & 3,98 & 0,97 \\
\hline 20.Para & 3,96 & 1,02 \\
\hline 21.Sadakat & 3,76 & 1,02 \\
\hline 22.Sorumluluk & 4,04 & 1,01 \\
\hline 23.Tarafsızlık & 4,10 & 1,04 \\
\hline 24.Tutumluluk & 4,02 & 1,08 \\
\hline 25. Uyum & 3,93 & 1,05 \\
\hline 26. Yaratıcılık & 3,91 & 1,07 \\
\hline 27. Yardımlaşma & 3,97 & 1,04 \\
\hline 28.Yeterlik & 4,01 & 1,07 \\
\hline 29.Zevk Almak & 3,93 & \\
\hline & & \\
\hline
\end{tabular}


Tablo 4 incelendiğinde, öğretmenlere göre okulların en yüksek düzeyde önemsediği beşörgütsel değer: Dürüstlük $(x=4,23, \mathrm{ss}=1,00)$, insana sayg1 $(x=4,20, \mathrm{ss}=0,99)$, adalet $(x=4,19, \mathrm{ss}=0,99)$, demokrasi $(x=4,18, \mathrm{ss}=0,96)$, çalışkanlıktır $(x=4,17, \mathrm{ss}=0,97)$. Başka bir anlatımla, öğretmenlere göre okullarda en fazla dürüstlük, insana saygı, adalet, demokrasi ve çalışkanlık değerlerine önem verilmektedir.

Araştırmanın üçüncü alt amacı; öğretmenlerin iş yaşamı kalite algıları ile okulların önemsediği örgütsel değerleri arasında anlamlı bir ilişki var mıdır, şeklindedir. "Kolerasyon katsayısı mutlak değer olarak "0,70-1,00" arasında olması yüksek ilişki; “0,70-0,30” arasında ise orta düzeyde bir ilişki; "0,30-0,00” arasında ise düşük düzeyde bir ilişkiyi göstermektedir" (Büyüköztürk, 2016, s.32). Bu açıklamalara göre Tablo 5'de öğretmenlerin iş yaşamı kalite algıları ile okulların önemsediği örgütsel değerler arasındaki ilişki düzeyi verilmiştir:

Tablo 5. Öğretmenlerin iş yaşamı kalitesi ile okulların önemsediği örgütsel değerler arasındaki ilişki

\begin{tabular}{lcc}
\hline Değişkenler & İş Yaşamı Kalitesi & Örgütsel Değerler \\
\hline İş Yaşamı Kalitesi & - &, $434^{*}$ \\
\hline$p<0,05^{*}$ & &
\end{tabular}

Tablo 5 incelendiğinde, öğretmenlerin iş yaşamı kalite algıları ile okulların önemsediği örgütsel değerler arasında pozitif yönlü orta derecede anlamlı bir ilişkinin olduğu göze çarpmaktadır. Başka bir anlatımla, okulların benimsediği örgütsel değer düzeyleri yükseldikçe, öğretmenlerin iş yaşamı kalite algı da olumlu yönde etkilenmektedir.

Araştırmanın dördüncü alt amacl; öğretmenlerin iş yaşamı kaliteleri, okulların önemsediği örgütsel değer algılarını anlamlı şekilde yordamakta mıdır? şeklindedir. Tablo 6'da okulların önemsediği örgütsel değerlerin yordanmasına ilişkin sonuçlar verilmiştir:

Tablo 6. Örgütsel değerlerin yordanmasına ait regresyon analiz sonucu

\begin{tabular}{lccccccc}
\hline Değişkenler & $\boldsymbol{B}$ & S.Hata & $\boldsymbol{\beta}$ & $\boldsymbol{t}$ & $\boldsymbol{p}$ & İkili $\boldsymbol{r}$ & Kısmi $\boldsymbol{r}$ \\
\hline Sabit & 3,012 & 0,197 & - & 15.260 &, 000 & - & - \\
\hline Toplam Yaşam Alanı & 0,106 & 0,055 & 0,087 & 1,941 &, 053 & 0,077 & 0,082 \\
\hline $\begin{array}{l}\text { Güvenli ve Sağlıklı Çalışma } \\
\text { Koşulları }\end{array}$ & 0,074 & 0,058 & 0,069 & 1,283 &, 200 & 0,051 & 0,054 \\
\hline $\begin{array}{l}\text { İş gören Kapasitesinin } \\
\text { Geliştirilmesi }\end{array}$ & 0,143 & 0,055 & 0,155 & 2,586 &, $010^{*}$ & 0,141 & 0,172 \\
\hline Sosyal Sorumluluk & 0,029 & 0,056 & 0,030 & 0,516 &, 606 & 0,120 & 0,220 \\
\hline Sosyal Bütünleşme & 0,014 & 0,065 & 0,013 & 0,217 &, 828 & 0,009 & 0,009 \\
\hline Demokratik Ortam & 0,269 & 0,059 & 0,263 & 4,572 &, $000^{*}$ & 0,328 & 0,253 \\
\hline Uygun ve Adil Karşıllık & 0,076 & 0,042 & 0,082 & 1,809 &, $017^{*}$ & 0,372 & 0,276 \\
\hline $\begin{array}{l}R=0,596, R^{2}=0,355 \\
F_{(7)}=6,126, p=.000^{*}\end{array}$ & & & & & & & \\
\hline$p<0,05^{*}$ & & & & & & &
\end{tabular}

Tablo 6 incelendiğinde, iş yaşam kalitesi alt boyut değişkenleri ile birlikte, okulların önemsediği örgütsel değerlerin yaşanması arasında anlamlı ilişki bulunmaktadır $\left(R=0,693, R^{2}=, 480, p<.05\right)$. 
Beş alt boyut, okulların önemsediği örgütsel değerdeki toplam varyansın \% 35'ni açılamıştır. Standardize edilen regresyon katsayısına $(\beta)$ göre, yordayıcı değişkenlerin örgütsel değer üzerinde göreceli önem sırası; demokratik ortam, iş gören kapasitesinin geliştirilmesi, toplam yaşam alanı, uygun ve adil karşılık, güvenli ve sağlıklı çalışma koşulları, sosyal sorumluluk ve sosyal bütünleşmedir. Regresyon katsayısının anlamlılı̆̆ına ait t-testi sonuçlarına bakıldığında, demokratik ortam, iş gören kapasitesinin geliştirilmesi, uygun ve adil karşıllk alt boyutları okulların önemsediği örgütsel değerler üzerinde önemli bir yordayıcıdır. Okulların önemsediği örgütsel değerlerin yordanmasına ilişkin regresyon eşitliği aşağıda verilmiştir:

Örgütsel Değer $=3,012+, 269$ Demokratik Ortam,+ 143 İş gören Kapasitesinin Geliştirilmesi + ,106Toplam Yaşam Alanı +,076Uygun ve Adil Karşılı + ,074Güvenli ve Sağlıklı Çalışma Koşulları + ,029Sosyal Sorumluluk,+ 014 Sosyal Bütünleşme.

Başka bir deyişle, öğretmenlerin iş yaşam kalitesi özelliklerinden, demokratik ortam, iş gören kapasitesinin geliştirilmesi ve uygun adil karşılık boyutları, okulların önemsediği örgütsel değerlerin anlamlı bir yordayıcısıdır.

Araştırmanın beşinci alt amacl, cinsiyet, branş ve okul türü değişkenleri ile öğretmenlerin iş yaşamı kalite algıları arasında anlamlı farklılık bulunmakta mıdır? şeklindedir. Tablo 7'de cinsiyete göre öğretmenlerin iş yaşamı kalite algı puan ortalamaları verilmiştir:

Tablo 7. Cinsiyete göre öğretmenlerin iş yaşamı kalite algılarının ilişkisiz $t$-testi sonuçları

\begin{tabular}{|c|c|c|c|c|c|c|}
\hline Faktör & Cinsiyet & $N$ & $x$ & ss & $t$ & $p$ \\
\hline \multirow{2}{*}{ Toplam Yaşam Alanı } & Kadın & 257 & 3,22 & 0,55 & \multirow{2}{*}{, 86} & \multirow{2}{*}{0,386} \\
\hline & Erkek & 311 & 3,17 & 0,60 & & \\
\hline \multirow{2}{*}{ Güvenli ve Sağlıklı Çalışma Koşulları } & Kadın & 257 & 3,35 & 0,66 & \multirow{2}{*}{$-3,01$} & \multirow{2}{*}{$0,003^{*}$} \\
\hline & Erkek & 311 & 3,52 & 0,65 & & \\
\hline \multirow{2}{*}{ İş gören Kapasitesinin Geliştirilmesi } & Kadın & 257 & 3,23 & 0,74 & \multirow{2}{*}{$-1,60$} & \multirow{2}{*}{0,109} \\
\hline & Erkek & 311 & 3,34 & 0,79 & & \\
\hline \multirow{2}{*}{ Sosyal Sorumluluk } & Kadın & 257 & 3,27 & 0,78 & \multirow{2}{*}{,- 89} & \multirow{2}{*}{0,370} \\
\hline & Erkek & 311 & 3,34 & 0,74 & & \\
\hline \multirow{2}{*}{ Sosyal Bütünleşme } & Kadın & 257 & 3,33 & 0,61 & \multirow{2}{*}{,- 49} & \multirow{2}{*}{0,619} \\
\hline & Erkek & 311 & 3,36 & 0,68 & & \\
\hline \multirow{2}{*}{ Demokratik Ortam } & Kadın & 257 & 3,48 & 0,68 & \multirow{2}{*}{$-2,19$} & \multirow{2}{*}{$0,029^{*}$} \\
\hline & Erkek & 311 & 3,61 & 0,70 & & \\
\hline \multirow{2}{*}{ Uygun ve Adil Karşılık } & Kadın & 257 & 2,63 & 0,70 & \multirow{2}{*}{$-3,04$} & \multirow{2}{*}{$0,002^{*}$} \\
\hline & Erkek & 311 & 2,82 & 0,81 & & \\
\hline
\end{tabular}

$p<0,05^{*}$

Tablo 7 incelendiğinde, cinsiyete göre öğretmenlerin toplam yaşam alanı $[t(566)=0,86, p>0,05]$, iş gören kapasitesinin geliştirilmesi [ $t(566)=-1,60, p>0,05]$, sosyal sorumluluk $[t(566)=-0,89, p>0,05]$, sosyal bütünleşme $[t(566)=-0,49, p>0,05]$ algıları arasında farklılık bulunmamıştır. Buna karşın cinsiyet değişkeni ile güvenli ve sağlıklı çalışma koşulları [ $t(566)=-3,01, p<0,05]$, demokratik ortam $[t(566)=-2,19, p<0,05]$, uygun ve adil karşılık $[t(566)=-3,04, p<0,05]$ algıları arasında farklılık bulunmuştur. Buna göre erkekler $(x=3,52$, ss=0,65), kadınlara $(x=3,35, \mathrm{ss}=0,66)$ nazaran daha fazla güvenli ve sağlıklı çalışma koşulları; erkekler $(x=3,61$, ss $=0,70)$, kadınlara göre $(x=3,48$, ss $=0,68)$ 
daha fazla demokratik ortam ve erkekler $(x=2,82$, ss $=0,81)$, kadınlara göre $(x=2,63$, ss $=0,70)$ daha fazla uygun ve adil karşllık olduğu görüşüne sahiptir. Başka bir anlatımla, erkek öğretmenlerin güvenli ve sağlıklı çalışma koşulları, demokratik ortam, uygun ve adil karşılıkuygun ve adil karşılık algı düzeyleri kadın öğretmenlere göre daha olumludur.

Tablo 8' de branş değişkenine göre öğretmenlerin iş yaşamı kalite algı puanlarının ilişkisiz t-Testi sonuçları verilmiştir:

Tablo 8. Branş değişkenine göre öğretmenlerin iş yaşamı kalite algılarımın ilişkisiz $t$-testi sonuçları

\begin{tabular}{|c|c|c|c|c|c|c|}
\hline Faktör & Kategori & $N$ & $x$ & ss & $t$ & $p$ \\
\hline \multirow{2}{*}{ Toplam Yaşam Alanı } & Sınıf Öğretmeni & 170 & 3,25 & 0,56 & \multirow{2}{*}{1,62} & \multirow{2}{*}{0,105} \\
\hline & Branş Öğretmeni & 398 & 3,17 & 0,58 & & \\
\hline \multirow{2}{*}{$\begin{array}{l}\text { Güvenli ve Sağlıklı Çalışma } \\
\text { Koşulları }\end{array}$} & Sınıf Öğretmeni & 170 & 3,53 & 0,64 & \multirow{2}{*}{1,98} & \multirow{2}{*}{$0,048^{*}$} \\
\hline & Branş Öğretmeni & 398 & 3,41 & 0,67 & & \\
\hline \multirow{2}{*}{$\begin{array}{l}\text { İş gören Kapasitesinin } \\
\text { Geliştirilmesi }\end{array}$} & Sınıf Öğretmeni & 170 & 3,41 & 0,72 & \multirow{2}{*}{2,49} & \multirow{2}{*}{$0,013^{*}$} \\
\hline & Branş Öğretmeni & 398 & 3,24 & 0,78 & & \\
\hline \multirow{2}{*}{ Sosyal Sorumluluk } & Sınıf Öğretmeni & 170 & 3,10 & 0,62 & \multirow{2}{*}{2,71} & \multirow{2}{*}{$0,007^{*}$} \\
\hline & Branş Öğretmeni & 398 & 2,91 & 0,68 & & \\
\hline \multirow{2}{*}{ Sosyal Bütünleşme } & Sınıf Öğretmeni & 170 & 3,47 & 0,65 & \multirow{2}{*}{3,03} & \multirow{2}{*}{$0,003^{*}$} \\
\hline & Branş Öğretmeni & 398 & 3,29 & 0,64 & & \\
\hline \multirow{2}{*}{ Demokratik Ortam } & Sınıf Öğretmeni & 170 & 3,64 & 0,68 & \multirow{2}{*}{1,92} & \multirow{2}{*}{0,055} \\
\hline & Branş Öğretmeni & 398 & 3,52 & 0,70 & & \\
\hline \multirow{2}{*}{ Uygun ve Adil Karşılık } & Sınıf Öğretmeni & 170 & 2,75 & 0,68 & \multirow{2}{*}{,38 } & \multirow{2}{*}{0,698} \\
\hline & Branş Öğretmeni & 398 & 2,73 & 0,81 & & \\
\hline
\end{tabular}

$p<0,05^{*}$

Tablo 8 incelendiğinde, branş değiş̧keni ile öğretmenlerin toplam yaşam alanı $[t(566)=1,62$, $p>0,05]$, demokratik ortam $[t(566)=1,92, p>0,05]$, uygun ve adil karşıllk $[t(566)=0,38, p>0,05]$ algiları arasında anlamlı fark bulunmamıştır. Buna karşın branş değişkeni ile güvenli ve sağlıklı çalışma koşulları [ $t(566)=1,98, p<0,05]$, iş gören kapasitesinin geliştirilmesi [ $t(566)=2,49, p<0,05]$, sosyal sorumluluk $[t(566)=2,71, p<0,05]$, sosyal bütünleşme $[t(566)=3,03, p>0,05]$ algıları arasında fark bulunmuştur. Buna göre sınıf öğretmenleri $(x=3,53$, ss=0,64) branş öğretmenlerine $(x=3,41$, $\mathrm{ss}=0,67)$ göre daha fazla güvenli ve sağlıklı çalışma koşullarl; sınıf öğretmenleri $(x=3,41$, $\mathrm{ss}=0,72)$, branş öğretmenlerine göre $(x=3,24, \mathrm{ss}=0,78)$ daha fazla iş gören kapasitesinin geliştirilmesi; sinıf öğretmenleri $(x=3,10, \mathrm{ss}=0,62)$, branş öğretmenlerine göre $(x=2,91, \mathrm{ss}=0,68)$ daha fazla sosyal sorumluluk ve sosyal bütünleşme $(x=3,47, \mathrm{ss}=0,65),(x=3,29, \mathrm{ss}=0,64)$ görüşüne sahiptir. Başka bir anlatımla, sınıf öğretmenleri branş öğretmenlerine göre iş gören kapasitesinin geliştirilmesi, güvenli ve sağlıklı çalışma koşulları, sosyal bütünleşme ve sosyal sorumluluk boyutlarına daha yüksek düzeyde katılım göstermiştir.

Tablo 9'da okul türü değişkenine göre öğretmenlerin iş yaşamı kalitesi betimsel istatistikleri verilmiştir: 
Tablo 9. Okul türü değişkenine göre öğretmenlerin iş yaşamı kalitesinin betimsel istatistikleri

\begin{tabular}{|c|c|c|c|}
\hline Toplam Yaşam Alanı & $N$ & $x$ & ss \\
\hline İlkokul & 133 & 3,28 & 0,64 \\
\hline Ortaokul & 138 & 3,27 & 0,55 \\
\hline Anadolu Lisesi & 131 & 3,03 & 0,57 \\
\hline İmam Hatip Lisesi & 80 & 3,23 & 0,51 \\
\hline Meslek Lisesi & 86 & 3,15 & 0,54 \\
\hline \multicolumn{4}{|c|}{ Güvenli ve Sağlıklı Çalışma Koşulları } \\
\hline İlkokul & 133 & 3,53 & 0,64 \\
\hline Ortaokul & 138 & 3,40 & 0,68 \\
\hline Anadolu Lisesi & 131 & 3,41 & 0,67 \\
\hline İmam Hatip Lisesi & 80 & 3,54 & 0,63 \\
\hline Meslek Lisesi & 86 & 3,33 & 0,66 \\
\hline \multicolumn{4}{|c|}{ İş Gören Kapasitesinin Geliştirilmesi } \\
\hline İlkokul & 133 & 3,44 & 0,75 \\
\hline Ortaokul & 138 & 3,30 & 0,78 \\
\hline Anadolu Lisesi & 131 & 3,16 & 0,79 \\
\hline İmam Hatip Lisesi & 80 & 3,24 & 0,69 \\
\hline Meslek Lisesi & 86 & 3,26 & 0,78 \\
\hline \multicolumn{4}{|l|}{ Sosyal Sorumluluk } \\
\hline İlkokul & 133 & 3,28 & 0,69 \\
\hline Ortaokul & 138 & 3,20 & 0,75 \\
\hline Anadolu Lisesi & 131 & 2,97 & 0,79 \\
\hline İmam Hatip Lisesi & 80 & 3,05 & 0,68 \\
\hline Meslek Lisesi & 86 & 2,95 & 0,70 \\
\hline \multicolumn{4}{|l|}{ Sosyal Bütünleşme } \\
\hline İlkokul & 133 & 3,50 & 0,65 \\
\hline Ortaokul & 138 & 3,43 & 0,69 \\
\hline Anadolu Lisesi & 131 & 3,26 & 0,65 \\
\hline İmam Hatip Lisesi & 80 & 3,30 & 0,63 \\
\hline Meslek Lisesi & 86 & 3,16 & 0,55 \\
\hline \multicolumn{4}{|l|}{ Demokratik Ortam } \\
\hline İlkokul & 133 & 3,66 & 0,68 \\
\hline Ortaokul & 138 & 3,64 & 0,69 \\
\hline Anadolu Lisesi & 131 & 3,45 & 0,70 \\
\hline İmam Hatip Lisesi & 80 & 3,54 & 0,62 \\
\hline Meslek Lisesi & 86 & 3,44 & 0,73 \\
\hline \multicolumn{4}{|l|}{ Uygun ve Adil Karşılık } \\
\hline İlkokul & 133 & 2,90 & 0,70 \\
\hline Ortaokul & 138 & 2,86 & 0,85 \\
\hline Anadolu Lisesi & 131 & 2,59 & 0,79 \\
\hline İmam Hatip Lisesi & 80 & 2,77 & 0,67 \\
\hline
\end{tabular}




\begin{tabular}{llll}
\hline Meslek Lisesi & 86 & 2,56 & 0,76 \\
\hline
\end{tabular}

Tablo 10. Okul türüne göre öğretmenlerin göre iş yaşamı kalite düzeylerinin varyans analizi sonucu

\begin{tabular}{|c|c|c|c|c|c|c|c|}
\hline Faktör & $\begin{array}{l}\text { Varyansın } \\
\text { Kaynağ1 }\end{array}$ & $\begin{array}{l}\text { Kareler } \\
\text { Toplamı }\end{array}$ & $d f$ & $\begin{array}{c}\text { Kareler } \\
\text { Ortalaması }\end{array}$ & $F$ & $p$ & Fark \\
\hline \multirow{3}{*}{$\begin{array}{l}\text { Toplam Yaşam } \\
\text { Alanı }\end{array}$} & Gruplararası & 5.638 & 4 & 1,409 & \multirow{3}{*}{4,29} & \multirow{3}{*}{$0,002^{*}$} & \multirow{3}{*}{$\begin{array}{l}\text { İlkokul- } \\
\text { Anadolu L. }\end{array}$} \\
\hline & Gruplariçi & 184.559 & 563 & 0,328 & & & \\
\hline & Toplam & 190.196 & 567 & & & & \\
\hline \multirow{3}{*}{$\begin{array}{l}\text { Güvenli ve Sağlıklı } \\
\text { Çalışma Koşulları }\end{array}$} & Gruplararası & 3,112 & 4 & 0,778 & \multirow{3}{*}{1,78} & \multirow{3}{*}{0,131} & \multirow{3}{*}{-} \\
\hline & Gruplariçi & 246,257 & 563 & 0,437 & & & \\
\hline & Toplam & 249,319 & 567 & & & & \\
\hline \multirow{3}{*}{$\begin{array}{l}\text { İş gören Kapasitesinin } \\
\text { Geliştirilmesi }\end{array}$} & Gruplararası & 5,660 & 4 & 1,415 & \multirow{3}{*}{2,42} & \multirow{3}{*}{$0,048^{*}$} & \multirow{3}{*}{$\begin{array}{l}\text { İlkokul- } \\
\text { Anadolu L. }\end{array}$} \\
\hline & Gruplariçi & 329,501 & 563 & 0,585 & & & \\
\hline & Toplam & 335,161 & 567 & & & & \\
\hline \multirow{3}{*}{ Sosyal Sorumluluk } & Gruplararası & 10,246 & 4 & 2,562 & \multirow{3}{*}{4,78} & \multirow{3}{*}{$0,001^{*}$} & \multirow{3}{*}{$\begin{array}{l}\text { İlkokul- } \\
\text { Meslek L. }\end{array}$} \\
\hline & Gruplariçi & 301,407 & 563 & 0,535 & & & \\
\hline & Toplam & 311,653 & 567 & & & & \\
\hline \multirow{3}{*}{ Sosyal Bütünleşme } & Gruplararası & 7,980 & 4 & 1,995 & \multirow{3}{*}{4,81} & \multirow{3}{*}{$0,001^{*}$} & \multirow{3}{*}{$\begin{array}{l}\text { İlkokul- } \\
\text { Meslek L. }\end{array}$} \\
\hline & Gruplariçi & 233,579 & 563 & 0,415 & & & \\
\hline & Toplam & 241,559 & 567 & & & & \\
\hline \multirow{3}{*}{ Demokratik Ortam } & Gruplararası & 5,130 & 4 & 1,282 & \multirow{3}{*}{2,70} & \multirow{3}{*}{$0,030^{*}$} & \multirow{3}{*}{$\begin{array}{l}\text { İlkokul- } \\
\text { Meslek L. }\end{array}$} \\
\hline & Gruplariçi & 267,153 & 563 & 0,475 & & & \\
\hline & Toplam & 272,283 & 567 & & & & \\
\hline \multirow{3}{*}{ Uygun ve Adil Karşılık } & Gruplararası & 10,122 & 4 & 2,530 & \multirow{3}{*}{4,36} & \multirow{3}{*}{$0,002^{*}$} & \multirow{3}{*}{$\begin{array}{l}\text { İlkokul- } \\
\text { Meslek L. }\end{array}$} \\
\hline & Gruplariçi & 326,268 & 563 & 0,580 & & & \\
\hline & Toplam & 336,390 & 567 & & & & \\
\hline
\end{tabular}

$p<0,05^{*}$

Tablo 9 ve Tablo 10 incelendiğinde, okul türü değişkenine göre öğretmenlerin iş yaşamı kalite düzeylerinde anlamlı farklılık elde edilmiştir. Buna göre ilkokul öğretmenlerinin toplam yaşam alanı ve iş gören kapasitesinin geliştirilmesi düzey algısı Anadolu lisesinde görev yapan öğretmenlere göre daha olumludur $(p<0,05)$. Ayrıca ilkokul öğretmenlerinin sosyal sorumluluk, demokratik ortam, sosyal bütünleşme, uygun ve adil karşılık algı durumları meslek lisesi öğretmenlerine göre daha olumludur.

\section{TARTIŞMA, SONUÇ VE ÖNERİLER}

Çalışmada öğretmenlerin iş yaşamı kalite algıları ile okulların önemsediği örgütsel değerler arasındaki ilişki farklı değişkenlere göre incelenmiştir. Araştırmada öğretmenler en yüksek sosyal bütünleşme; en düşük düzeyde uygun ve adil karşlılk boyutuna katılım göstermiştir. Öğretmenlere göre okullarda sosyal bütünleşme kolaylıkla uygulanırken, işlerine yönelik uygun 
ve adil karşılık tam olarak sağlanamamaktadır. Taşdan ve Erdem (2010) yapmış oldukları çalışmada öğretmenlerin en yüksek demokratik ortam ve sosyal bütünleşme; en az uygun ve adil karşılık boyutlarına katılım gösterdiklerini belirlemiştir. Benzer bulgu Demir (2016), Demir (2019), Hart (1994), Kösterelioğlu (2011), Yalçın (2014) tarafından da belirlenmiştir. Baleghizadeh ve Gordani (2012) öğretmenlerin en düşük uygun ve adil karşılık, en yüksek sosyal bütünleşme görüşüne sahip olduklarını belirlemiştir. Bu sonuçlar araştırma bulgularını desteklemektedir. Araştırma sonuçlarından farklı olarak Yılmaz (2019) göre öğretmenler en yüksek demokratik ortam, en az da toplam yaşam alanı boyutuna katılımda bulunmuştur. Öğretmenlerin aldıkları ücretin yeterli olmadığı (Özdemir, 1986), bu duruma bağlı olarak bilimsel yayınları dahi takip edemedikleri (Özdayı, 1990) ve geçim sıkıntısı yaşadıkları için ek iş yapmak zorunda oldukları (Özpolat, 2002) belirlenmiştir. Erdem (2008)'e göre devlet okullarında görev yapan lise öğretmenlerinin en düşük uygun ve adil karşllık, toplam yaşam alanı; en yüksek sosyal sorumluluk ve demokratik ortam boyutunda katılım sağlamışlardır. Uygun ve adil karşılık boyutuna katılımın düşük olması araştırma sonuçları ile örtüşmektedir. Bu sonuç öğretmenlerin maaş, emeklilik, sağlık ve özlük hakları konusunda yetersizlik, memnuniyetsizlik duymalarından kaynaklanabilir. Kazandıkları ücretin yaptıkları işin karşılı̆̆ı olmadığını düşünmelerinin bir yansıması olabilir.

Araştırmada öğretmenlere göre okulların önemsediği en yüksek düzeyde örgütsel değerler dürüstlük, insana saygı ve adalet olmuştur. Öğretmenler okul kültürü içerisinde dürüstlük, insana sayg1 ve adalet ilkelerinin yüksek düzeyde önemsendiğini düşünmektedir. McDonald ve Gandz (1992), Özmete ve Gönen (1997), Sağnak (2005), Taşdan (2008), Taşdan ve Erdem'in (2010) yaptıkları çalışmada öğretmenlere göre okul ortamı içinde en çok önemli görülen değerler; dürüstlük, insana saygı ve adalettir. Bu sonuçlar araştırma sonuçları ile paralel niteliktedir. Taşdan (2010) yılındaki çalışmasında öğretmenlere göre okul ortamı içinde en çok önem verilen beş örgütsel değer: Çalışkanlık, başarı, kalite, dürüstlük ve insan odaklılık olarak belirlemiştir. Benzer bir çalışmada öğretmenler okullarda önem verilen örgütsel değerleri; dürüstlük, güven, saygı olarak belirtmiştir (Sezgin, 2007). Öğretmenlerin okulların önemsediği örgütsel değerler açısından özellikleri incelendiğinde, bu değerlerin insan ilişkilerine dönük, ilişki yönelimli, eşitlik anlayışına doğru olduğu gözlenmektedir. Bu durum Hofstede (1984)'in kültürler arası değer farklılıklarına ait araştırmasında gösterdiği gibi, Türkiye'nin kültürel yönden dişil kültürü yansıtan toplumsal yapısından kaynaklanabilir. Çünkü insanlar arası ilişkilere ve insana verilen değer, anlayış, saygı, adalet ve duyarlılık tarzındaki değerler de kültürün dişi özellikte olduğuna işaret edilmektedir (Sargut, 2001). Bu açıklamalardan hareketle, araştırma sonucunda elde edilen sonuçların, daha önceki araştırma bulgularını destekler niteliktedir.

Araştırmada öğretmenlerin iş yaşamı kalite algıları ile okulların önemsediği örgütsel değer algıları arasında pozitif yönde orta düzeyde anlamlı bir ilişkinin olduğu belirlenmiştir. Bu bulgu Özmete ve Gönen (1997), Taşdan ve Erdem (2010) çalışma sonucu ile benzer niteliktedir. Örgütsel değerler içerisinde yer alan tarafsızlık, adalet, demokrasi, eşitlik kavramları iş yaşamı kalitesinin demokratik ortam boyutuyla pozitif yönde bir ilişki içerisindedir. Bu değerlere önem verilmesi ve yaşanması demokratik ortamı olumlu yönde iyileştirecektir. İş birliği, insana saygı, iyilikseverlik, fedakârlık sorumluluk, uyum, yardımlaşma değerlerinin de iş yaşamı kalitesinin sosyal bütünleşme ve sosyal sorumluluk boyutları ile doğrudan ilgilidir. Bu sonuçlardan iş birliği, insana saygı, iyilikseverlik, fedakârlık sorumluluk, uyum, yardımlaşma değerleri ile sosyal bütünleşme ve sosyal sorumluluk arasında pozitif yönde bir ilişkinin olması beklenen bir olgudur. 
Araştırmada öğretmenlerin demokratik ortam, uygun ve adil karşıllk ve iş gören kapasitesinin geliştirilmesi boyutlarının okulun önemsediği örgütsel değerler üzerinde pozitif yönlü anlamlı bir yordayıcı olduğu belirlenmiştir. Bu sonuç Taşdan ve Erdem (2010) araştırma sonucu ile paralel niteliktedir. İş gören kapasitesinin geliştirilmesinin çalışkanlık, uyum ve bağımsızlık; demokratik ortam, uygun ve adil karşılığın ise tarafsızlık, adalet, eşitlik, insana saygı kavramı ile bağdaştığı ve birbirini pozitif yönde beslediği bilinmektedir. Bu doğrultuda demokratik ortam, uygun ve adil karşılık, iş gören kapasitesinin geliştirilmesi özelliğine sahip olan öğretmenlerin, okulun benimsediği örgütsel değerler üzerinde yüksek etki bırakması beklenen bir sonuçtur.

Araştırmada cinsiyete göre, öğretmenlerin uygun ve adil karşılık, demokratik ortam, güvenli ve sağlıklı çalışma koşulları boyutları anlamlı olarak farklılaşırken, sosyal bütünleşme, toplam yaşam alanı, sosyal sorumluluk, iş gören kapasitesinin geliştirilmesi anlamlı olarak farklılaşmamıştır. Erkek öğretmenler kadın öğretmenlere oranla daha fazla uygun ve adil karşılık, demokratik ortam, güvenli ve sağlıklı çalışma koşulları görüşüne sahiptir. Erdem (2008) ve Yılmaz (2014)'de yapmış oldukları çalışmalarda erkek öğretmenler, kadın öğretmenlere göre güvenli ve sağlıklı çalışma koşulları, demokratik ortam ve uygun ve adil karşılık alt boyutunu daha yeterli bulmuşlardır. Bu sonuç araştırma bulgusuyla paralel niteliktedir. Karakaya ve Çoruk (2017), Toygar vd.'nin (2018) elde ettiği sonuçlar araştırma bulgularını desteklemektedir. Çalışmada elde edilen bu sonuçtan farklı olarak cinsiyete göre öğretmenlerin iş yaşam kalitesi algıları anlamlı farklılık göstermemektedir (Demir, 2019). Divins vd., 1991 yılında gerçekleştirdiği çalışmada kadın öğretmenlerin iş yaşamı kalite algıları erkek öğretmenlere göre daha yüksek olduğunu belirlemiştir. Ayrıca Yılmaz (2019)'a göre öğretmenlerin psikolojik dayanıklıkları ile iş yaşamı kalitesi arasındaki ilişkiyi araştırdığı çalışmasında, cinsiyete göre öğretmenlerin toplam yaşam alanı, uygun ve adil karşılık, sosyal bütünleşme, demokratik ortam, iş gören kapasitesinin geliştirilmesi, sosyal sorumluluk, güvenli ve sağlıklı çalışma koşulları hakkındaki düşünceleri anlamlı farklılık göstermemiştir. Erdem (2008)'e göre kamu liselerinde görevli kadın öğretmenlerin toplam yaşam alanı alt boyutuna katılım gösterme halleri, erkek öğretmenlere göre; erkek öğretmenlerinde sosyal bütünleşme algıları kadın öğretmenlere göre daha yüksektir. Demokratik ortam algısının düşük olması açısından kadın öğretmenlerin, erkek öğretmenlere göre kişisel düşüncelerini daha rahat ifade edemediklerinin sonucu olabilir. Günümüzde okullarda yaşanan öğrenci-öğretmen şiddeti, güvenli olmayan okul konumları, yönetimde yaşanan birtakım adil olmayan uygulamalar, öğretmenler arasındaki dedikodu ve olumsuz ilişkilerin varlığı, kadın öğretmenlerin kendilerini güvenli ve sağlıklı bir çalışma ortamında hissetmemelerine neden olduğu ileri sürülebilir.

Araştırmada öğretmenlerin branş değişkeni ile toplam yaşam alanı, uygun ve adil karşılık, demokratik ortam alt boyutları arasında anlamlı farklılık bulunmazken; iş gören kapasitesinin geliştirilmesi, sosyal sorumluluk, güvenli ve sağlıklı çalışma koşulları ve sosyal bütünleşme ile farklılık elde edilmiştir. Sınıf öğretmenlerinin, iş gören kapasitesinin geliştirilmesi, güvenli ve sağlıklı çalışma koşulları, sosyal bütünleşme ve sosyal sorumluluk algıları branş öğretmenlerine göre daha olumludur. Divins vd., (1991)'e göre ilkokul öğretmenlerinin iş yaşamı kalite düzeyleri ortaokul öğretmenlerine göre daha olumludur. Bu bulgu araştırma sonuçları ile paralel düzeydedir. Buna karşın Çelik ve Tabancalı (2012), Yılmaz (2014)'de gerçekleştirdiği çalışmalarda öğretmenlerin branş değişkeni ile iş yaşamı kalite algıları arasında anlamlı farklılık elde edilmemiştir. Ayrıca Yılmaz (2019)'a göre sınıf öğretmenleri ile branş öğretmenlerinin toplam yaşam alanı, uygun ve adil karşılık, sosyal bütünleşme, demokratik ortam, güvenli ve sağlıklı çalışma koşulları ve iş gören kapasitesinin geliştirilmesi alt boyut düzeyleri anlamlı olarak farklılaşmamıştır. Ancak "sınıf öğretmenlerinin sosyal sorumluluk algıları branş 
öğretmenlerine göre anlamlı olarak daha yüksektir" (Yılmaz, 2009, s. 66). Bu bulgu araştırma sonuçlarını destekler niteliktedir. Sınıf öğretmenlerinin branş öğretmenlerine göre iş gören kapasitesinin geliştirilmesi, güvenli ve sağlıklı çalışma koşulları, sosyal bütünleşme ve sosyal sorumluluk alt boyutlarını algılama düzeylerinin yüksek çıkmasında, okullarında kendilerini daha güvenli hissetmelerinin, yeteneklerini daha üst düzeyde kullanabildiklerinin, sosyal çalışmalara daha çok ağırlık verildiğinin, iş birliği ve aitlik duygularının daha baskın olmasından kaynaklanabilir. Sınıf öğretmenlerinin dört yıl boyunca aynı öğrenci ve veli kitlesi ile muhatap olması kendilerinde bir güven hissi yaratmasından kaynaklanabilir.

İlkokul öğretmenlerinin iş gören kapasitesinin geliştirilmesi ve toplam yaşam alanı düzeyleri Anadolu lisesinde görev yapan öğretmenlere göre daha olumludur. Ayrıca ilkokul öğretmenlerinin sosyal bütünleşme, demokratik ortam, sosyal sorumluluk, uygun ve adil karşllık alt boyutlarına ilişkin algı durumları, meslek lisesi öğretmenlerinden daha yüksektir. Alan yazın taraması sonucunda ulusal ve uluslararası çalışmalarda iş yaşamı kalitesi ile okul türü değişkenini ele alan kısıtlı araştırma bulunmaktadır. Araştırma sonuçlarından farklı olarak okul türüne göre öğretmenlerin toplam yaşam alanı, uygun ve adil karşıllı, demokratik ortam, güvenli ve sağlıklı çalışma koşullarına ait düşünceleri anlamlı farklılık göstermemiştir (Yılmaz, 2019). Ancak ilkokul öğretmenlerinin sosyal sorumluluk, iş gören kapasitesinin geliştirilmesi ve sosyal bütünleşme düzeyleri lise öğretmenlerine göre daha yüksek düzeydedir (Yılmaz, 2019). Bu bulgu araştırma sonuçlarıyla paralel niteliktedir. İlkokul öğretmenlerinin lise öğretmenlerine göre okullarına karşı uyum, iş birliği, aitlik, adalet, ücret ve özlük hakları, çalışma şartları, iş yaşamı memnuniyeti, mesleki gelişim, inovasyon noktasında daha olumlu duygulara sahip olmalarından kaynaklanabilir.

Çalışma sonuçlarından yola çıkılarak aşağıdaki öneriler sunulmuştur.

- Öğretmenlerin özlük, ek ders yönetmeliği, atama ve görevde yükselme olanakları, mesleki ve emeklilik hakları düzenlenerek iyileştirilebilir. Yönetim anlayışı adalet, eşitlik, tarafsızlık ilkelerine bağlı kalınarak geliştirilebilir. Öğretmenlerin bu konudaki görüş ve düşünceleri daha sık alınabilir.

- Öğretmenlerin öncelik verdikleri değerlere yönelik bir yönetim anlayışı oluşturulabilir. Sosyal sorumluluk projelerinin sayısı arttırılarak okul içindeki sinerjik ortam güçlendirilebilir.

- Öğretmenlerin iş yaşamı kaliteleri, örgütsel değer algılarından sadakat ve özdenetim anlayışını yükseltecek politika, farkındalık eğitimleri, örgütsel bağlılığı güçlendirecek uygulamalar geliştirilebilir.

- Öğretmenlerin okullardaki çalışma koşulları düzenlenerek demokratik bir yönetim anlayışı, fiziki donanım ve kapasite, maaş ve hakların iyileştirilmesi, 21 yy. becerilerini geliştirmeye yönelik hizmet içi eğitimlerin sayısı arttırılabilir ve nitelikleri yükseltilebilir.

- Kadın öğretmenlerin okullarına dair güvenli ve sağlıklı çalışma koşullarını yükseltmek için, iletişim becerileri, farkındalık eğitimleri verilerek güvenli ve sağlıklı çalışma ortamları iyileştirilebilir.

- Branş öğretmenlerinin okullarına yönelik sosyal sorumluluk ve sosyal bütünleşme algılarını yükseltebilmek için çevreye yönelik etkinlikler, kültür-sanat ve yardım faaliyetleri düzenlenebilir, sayıları arttırılabilir.

- Lise öğretmenlerinin okullarına yönelik iş yaşamı kalite algılarını iyileştirecek, olumlu hale getirecek programlar ve uygulamalar geliştirilebilir. Bu bağlamda okul yöneticileri süreç odaklı bir yönetim anlayışı uygulayabilir. 
- Özel okullarda görev yapan öğretmenler için de aynı çalışma yapılıp kamu ve özel okullarda görevli öğretmenlerin iş yaşamı kalite algıları ile örgütsel değerleri arasındaki ilişki kıyaslanarak eksik kalınan noktalar belirlenebilir.

- Çalışma Kayseri ilinin merkez ilçelerinde görevli öğretmenler için yapılmıştır. Kayserinin diğer ilçeleri içinde benzer çalışma yürütülerek ilçeler arasında karşılaştırma yapilabilir.

- Farklı coğrafik bölgeler, şehir ve sosyoekonomik düzeydeki okullar için de çalışma yürütülerek şehirler ve bölgeler arası kıyaslamalar yapılabilir.

- Araştırma okul yöneticileri, şube müdürleri, ilçe ve il milli eğitim müdürlerine yönelik de yapılarak çalışma kapsamı genişletilebilir.

\section{KAYNAKÇA / REFERENCES}

Akman, Y., ve Akman, G. İ. (2017). İlköğretim okulu öğretmenlerinin iş yaşam kalitesi algısının işle bütünleşmeleri üzerindeki etkisi. Elementary Education Online, 16(4), 1491-1504.

Baleghizadeh, S. and Gordani, Y. (2012). Motivation and quality of work life among secondary school EFL teachers. Australian Journal of Teacher Education,37(7), 30-42. http://dx.doi.org/10.14221/ajte.2012v37n7.8

Barker, J. D. (1986). Influence of quality of work life variables on the retention and career satisfaction of science and mathematics teachers [Unpublished doctoral dissertation]. The University of Tennessee.

Beach, D. S. (1980). Personnel the management of people at work (4 th Edition). Macmillan Publishing.

Beechem, M. H. (1985). An overview of quality of work life-quality circles in United States institutions of higher education (participative management, problem-solving groups, Japanese, employee involvement) [Unpublished doctoral dissertation). Michigan State University.

Bilgin, N. (1995). Sosyal psikolojide yöntem ve pratik çalışmalar. Sistem Yayıncllık.

Bolduc, R. R. (2002). An analysis of the relationship between quality of work life and motivation for correctional services officers in the montreal area [Unpublished doctoral dissertation]. McGill University.

Boxx, W. R., Odom R. Y., ve Dunn, M. G. (1991). Organizational values and value congruency and their impact on satisfaction, commitment, and cohesion: An empirical examination within the public sector. Public Personnel Management, 20(1), 195-205. https://doi.org/10.1177\%2F009102609102000207.

Büyüköztürk, Ş. (2016). Sosyal bilimler için veri analizi el kitabı (22. Baskı). Pegem Akademi.

Chatman, J. A. (1989). Improving interactional organizational research: A model of personorganization fit. Academy of Management Review, 14(3), 333-349. https://doi.org/10.5465/amr.1989.4279063.

Çelik, K., ve Tabancalı, E. (2012). Özel eğitim kurumlarında çalışan öğretmenlerin iş/çalışma yaşam kalitesi. Akdeniz Ĕ̆itim Araştırmaları Dergisi, 11, 31-38. ISSN: 1309-0682.

Çokluk, Ö. (2003). Örgütlerde tükenmişlik. In C. Elma, K. Demir (Ed.), Yönetimde çağdaş yaklaşımlar (2nd ed., ss. 243-259). Anı Yayınları.

Demir, T. (2016). Meslek lisesi öğretmenlerinin iş yaşam kalitesine ilişkin alg̨ları ile örgütsel bă̆lllık düzeyleri arasındaki ilişki [Yayınlanmamış yüksek lisans tezi]. İstanbul Sabahattin Zaim Üniversitesi, İstanbul.

Demir, E. (2019). Öğretmenlerin iş yaşam kalitesi ile pozitif psikolojik sermaye düzeyleri arasındaki ilişkinin incelenmesi [Yayınlanmamış yüksek lisans tezi]. İnönü Üniversitesi. Malatya. 
Divins, B., Guerriero, S. J., William, E., Snell, J. R., Livers, J. (1991). The hidden factor in early field experience: teachers' perception of the quality of life at work. https://files.eric.ed.gov/fulltext/ED378133.pdf.

Elma, C. (2003). Illköğretim okul öğretmenlerinin işe yabancilaşması (Ankara ili örneği) [Yayımlanmamış doktora tezi]. Ankara Üniversitesi, Ankara.

Erdem, M. (2008). Öğretmenlere göre kamu ve özel liselerde iş yaşamı kalitesi ve örgütsel bağlllıkla ilişkisi [Yayımlanmamış doktora tezi]. Ankara Üniversitesi. Ankara.

Erdem, M. (2010). Öğretmen algılarına göre liselerde iş yaşamı kalitesi ve örgütsel bağlılıkla ilişkisi. Kuram ve Uygulamada Eğitim Yönetimi Dergisi, 16(4), 511-537.

Feather, N. T. and Rauter, K. A. (2004). Organizational citizenship behaviours in relation to job status, job insecurity, organizational commitment and identification, job satisfaction and work values. Journal of Occupational and Organizational Psychology, 77(1), 81-94. https://doi.org/10.1348/096317904322915928.

Fraenkel, J. R. and Wallen, M. E. (2009). How to design and evaluate research in education (7th ed.). MacGraw-Hill

Gizzi, A. (1988). Socio-technical systems/quality of working life (STS/QWL) alternative paradigm: an urban secondary school experience (1982-1983) [Unpublished doctoral dissertation]. University of Massachusetts Amherst.

Hamm, S. (2006). Understanding value congruence: a sport organization case study [Published master thesis]. University of St. Catharines, Ontario.

Hart, P. M. (1994). Teacher quality of work life: integrating work experiences, psychological distress and morale. Journal of Occupational and Organizational Psychology, 67(2), 109-132. https://doi.org/10.1111/j.2044-8325.1994.tb00555.

Hofstede, G. (1984). Cultural dimensions in management and planning. Asia Pacific journal of management, 1(2), 81-99. https://doi.org/10.1007/BF01733682.

Hyde, P.and Williamson, B. (2000). The importance of organisational values part 1: Is your organisation value congruent? Focus on Change Management, 66, 14-18. http://peterhyde.co.uk/wp-content/uploads/2013/09/Part-1-Is-your-organisationvaluecongruent.pdf

Karakaya, Ç. H. ve Çoruk, A. (2017). İlköğretim okullarında görev yapan öğretmenlerin okul yaşam kalitesi algıları ile iş doyumu algıları arasındaki ilişki. Dicle University Journal of Ziya Gokalp Education Faculty, 31, 751-761. https://doi.org/10.14582/DUZGEF.1838.

Kaya, B. (2008). Sosyal Bilgiler öğretmen adaylarının düşünme becerilerinin öğretimine yönelik öz yeterliklerinin değerlendirilmesi [Yayımlanmamış doktora tezi]. Gazi Üniversitesi, Ankara.

Kösterelioğlu, A. M. (2011). İlköğretim okulu öğretmenlerinin iş yaşam kalitesi ile işe yabancılaşması arasındaki ilişki [Yayımlanmamış doktora tezi]. Abant İzzet Baysal Üniversitesi, Bolu.

Lewis, P. S., Goodman, S. H. and Fandt, P. M. (1998). Challenges in the 21 st century management (2nd Edition). South-Western Publishing Company.

Martel, J. P. and Dupuis, G. (2006). Quality of work life: Theoretical and methodological problems, and presentation of a new model and measuring instrument. Social indicators research, 77(2), 333-368. DOI 10.1007/s11205-004-5368-4.

McDonald, P. and Gandz, J. (1991). Identification of values relevant to business research. Human Resource Management, 30(2), 217-236. https://doi.org/10.1002/hrm.3930300205.

McDonald, P. and Gandz, J. (1992). Getting value from shared values. Organizational Dynamics, 20(3), 64-77. https://doi.org/10.1016/0090-2616(92)90025-I. 
O'Reilly, C. A., Chatman, J., ve Caldwell, D. F. (1991). People and organizational culture: a profile comparison approach to assessing person-organization fit. Academy of Management Journal, 34 (3), 487- 517. https://doi.org/10.5465/256404.

O'Reilly, C. A. and Chatman, J. A. (1996). Culture as social control: Corporations, cults, and commitment. In B. M. Staw ve L. L. Cummings (Eds.), Research in organizational behavior: An annual series of analytical essays and critical reviews, (18nd ed., pp. 157-200). Elsevier Science/JAI Press.

Özdayı, N. (1990). Resmi ve özel liselerde çalı̧̧an öğretmenlerin iş tatmini ve iş streslerinin karşılaştırmalı analizi [Yayımlanmamış doktora tezi]. İstanbul Üniversitesi, İstanbul.

Özdemir, S. (1986). Kamu ödeme sistemi içinde öğretmen ücretlerinin yeri ve sağladığı doyum [Yayımlanmamış yüksek lisans tezi]. Ankara Üniversitesi, Ankara.

Özmete, E. Y., ve Gönen, E. T. D. (1997). Değerlerin yaşam kalitesi üzerindeki rolü (Tokat örneği) [Yayımlanmamış doktora tezi] . Ankara Üniversitesi, Ankara.

Özpolat, A. (2002). Sosyolojik açıdan öğretmenlik mesleği ve öğretmenlerin toplumdaki yeri, öğretmen, öğrenci ve veli algılarına göre (Zonguldak örneği) [Yayımlanmamış doktora tezi]. İstanbul Üniversitesi, İstanbul.

Pang, N. S. K. (1996). School values and tcachers' feelings: A LISREL Model. Journal of Educational Administration, 34(2), 64-83. https://doi.org/10.1108/09578239610112114.

Pillay, H., Goddard, R. and Wilss, L. (2005). Well-being, burnout and competence: implications for teachers. Australian Journal of Teacher Education, 30(2), 21-33. http://dx.doi.org/10.14221/ajte.2005v30n2.3.

Posner, B. Z., Kouzes, J. M. and Schmidt, W. H. (1985). Shared values make a difference: an empirical test of corporate culture. Human Resource Management, 24(3), 293-309. https://doi.org/10.1002/hrm.3930240305.

Rashid Z. A., Sambasivan M. and Johari J. (2003). The influence of corporate culture and organisational commitment on performance. Journal of Management Development, 22(8), 708-728. https://doi.org/10.1108/02621710310487873.

Safrit, D. R., Jones, J. M. and Conklin, N. L. (1994). Clarifying Ohio State University extension's organizational values. Journal of Extension, 32(2), 1-3.

Sağnak, M. (2005). İlköğretim okullarında görevli yönetici ve öğretmenlerin örgütsel değerlere ilişkin algıları. Ĕgitim ve Bilim, 30(135), 50-57.

Sargut, A. S. (2001). Kültürlerarası farklılaşma ve yönetim (2. Baskı). İmge Kitabevi.

Shobe, R. E. (1983). Quality of work life as perceived by elementary school principals and by elementary school teachers [Unpublished doctoral dissertation]. Indiana State University.

Şimşek, Ö. F. (2007), Yapısal eşitlik modellemesine giriş. Ekinoks Yayınları.

Tabachnick, B. G. and Fidell, L. S. (2007). Experimental designs using ANOVA. Thomson/Brooks/Cole.

Tanrıöğen, A. (2009). Bilimsel araştırma yöntemleri. Anı Yayıncılık.

Taşdan, M. (2008). Türkiye'deki kamu ve özel ilköğretim okulu öğretmenlerinin bireysel değerleri ile okulun örgütsel değerleri arasındaki uyum düzeyi, iş doyumu ve algılanan sosyal destek ilişkisi [Yayımlanmamış yüksek lisans tezi]. Ankara Üniversitesi, Ankara.

Taşdan, M. (2010). Türkiye'deki resmi ve özel ilköğretim okulu öğretmenlerinin bireysel değerleri ile okulun örgütsel değerleri arasındaki uyum düzeyi. Kuram ve Uygulamada Eğitim Yönetimi Dergisi, 16(1), 113-148.

Taşdan, M., ve Erdem, M. (2010). İlköğretim okulu öğretmenlerinin iş yaşamı kalitesi ile örgütsel değer algıları arasındaki ilişki düzeyi. Yüzüncü Yıl Üniversitesi, Eğitim Fakültesi Dergisi, $7(2), 92-113$. 
Erciyes Journal of Education 2021, Vol 5, No 1, 51-73

Uyan, G. (2002). Öğretmenlerin iş değerleri, kişilik özellikleri ve iş tatminleri arasındaki ilişkilerin incelenmesi: MEB'na bağlı resmi ve özel eğitim kurumlarında gerçekleştirilen bir araştırma [Yayımlanmamış yüksek lisans tezi]. İstanbul Üniversitesi, İstanbul.

Walton, R. E. (1975). Criteria for quality of work life. Free Press.

Yalçın, S. (2014). Öğretmenlerin algularına göre okul yöneticilerinin stilleri ile öğretmenlerin iş yaşam kalitesi ve örgütsel bağlılık düzeyleri arasındaki ilişkinin incelenmesi [Yayımlanmış doktora tezi]. Atatürk Üniversitesi, Erzurum.

Yalçın, S., Yıldırım, İ., ve Akan, D. (2016). Öğretmenlerin iş yaşam kaliteleri ile örgütsel bağlılıkları arasındaki ilişkinin incelenmesi. Erzincan Üniversitesi Eğitim Fakültesi Dergisi, 18(1), 205-224. http://dx.doi.org/10.17556/jef.49471.

Yılmaz, K. (2007). İlköğretim okulu yönetici ve öğretmenlerinin değerlere göre yönetim ile ilgili görüşleri. Kuram ve Uygulamada Ĕ̆itim Yönetimi, 52(52), 639-664.

Yılmaz, M. (2019). Öğretmenlerin psikolojik dayanıklkkları ile iş yaşam kaliteleri arasındaki ilişki [Yayımlanmamış yüksek lisans tezi], Erzincan Binali Yıldırım Üniversitesi, Erzincan. 